\title{
Introducing the sixth edition of the Canadian Tuberculosis Standards
}

\author{
Richard Long $\mathrm{MD}^{1}$, Edward Ellis $\mathrm{MD}^{2}$
}

$\mathrm{T}$ he sixth edition of the Canadian Tuberculosis Standards will soon be available in hard copy through the offices of the Canadian Lung Association (CLA), and the individual provincial and territorial lung associations, and in PDF format at <www.publichealth.gc.ca/tuberculosis>.

Historically, the Standards became important when effective treatment of tuberculosis became available and sanatoria closed. In contrast to the first (1972), second (1981), third (1988) and fourth (1996) editions, which were products of the Canadian Thoracic Society (CTS)/CLA alone, the fifth (2000) and sixth editions of the Standards were jointly produced by the CTS/CLA and Health Canada (fifth), and the Public Health Agency of Canada (PHAC) (sixth). The evolution of the Standards as a document dependent on the CTS for medical and scientific input, and on the PHAC for public health and policy input, was part of a broader shift from nongovernmental to governmental organization of tuberculosis prevention and control activity in Canada.

The Tuberculosis Prevention and Control Program of the PHAC is the sponsor of the Canadian Tuberculosis Committee, a national committee with representation from each province and territory, Citizenship and Immigration Canada, First Nations and Inuit Health Branch of Health Canada, Correctional Service Canada, Canadian Public Health Laboratory Network, Association of Medical Microbiology and Infectious Disease, CLA, CTS and PHAC (both the National Microbiology Laboratory and the Tuberculosis Prevention and Control Program). It also houses the Canadian Tuberculosis Surveillance System and the Canadian Tuberculosis Laboratory Surveillance System, as well as represents Canada internationally. The major role of the Tuberculosis Committee of the CTS is now the preparation of the Standards. In fact, the membership of the CTS Tuberculosis Committee and the editorial committee of the Standards are one and the same; the editors of the Standards are the Chair of the CTS Tuberculosis Committee and the Manager of the Tuberculosis Prevention and Control Program of the PHAC.

The sixth edition of the Standards is a substantial revision to its predecessor the fifth edition (see below). Chapters or appendixes already in the fifth edition were redacted, and new chapters and appendixes were added (Chapters 14, 15 and 18; Appendixes D, E, F, G, H and J) after a systematic survey of end-user satisfaction with the fifth edition undertaken by the CTS. In addition to the chapter-specific table of contents and expanded bibliographies, the text is populated with a series of Web resources that will be regularly updated by PHAC and other agencies. As in the fifth edition, treatment recommendations are rated using a roman numeral (I, II or III), which indicates the quality of evidence supporting the recommendation (1). The Standards are meant to be a definitive resource on issues pertaining to tuberculosis prevention and control in Canada. In contrast to provincial and territorial guidelines, which describe how an action is to be accomplished and how the structure of care is framed, the Canadian Tuberculosis Standards, like the International Standards for Tuberculosis Care (available at <www.nationaltbcenter.edu/international/>), provide the foundation on which care can be based, presenting what should be done.

\section{REFERENCES}

1. Gross PA, Barrett TL, Dellinger EP, et al. Purpose of quality standards for infectious diseases. Infectious Diseases Society of America. Clin Infect Dis 1994;18:421

\section{CANADIAN TUBERCULOSIS STANDARDS, SIXTH EDITION (2007)}

\section{Preface}

\section{Acknowledgements}

Epidemiology

Chapter $1 \quad$ Epidemiology of tuberculosis in Canada Melissa Phypers, Dennis Kunimoto, Marcel Behr, Derek Scholten, Edward Ellis

\section{Medical aspects of tuberculosis}

Chapter 2 Mycobacteriology laboratory standards: Services and policies

Joyce Wolfe, Kym Antonation,

Meenu Kaushal Sharma

Chapter 3 Transmission and pathogenesis of tuberculosis Richard Long, Kevin Schwartzman

Chapter 4 Diagnosis of tuberculosis infection and disease

Dick Menzies, Kamran Khan

${ }^{1}$ Tuberculosis Committee of the Canadian Thoracic Society of the Canadian Lung Association; ${ }^{2}$ Tuberculosis Prevention and Control Program, Public Health Agency of Canada, Ottawa, Ontario

Correspondence and reprints: Dr Richard Long, Tuberculosis Program Evaluation and Research Unit, Room 8325, Aberhart Hospital, 11402 University Avenue, Edmonton, Alberta T6G 2J3. Telephone 780-407-1427, fax 780-407-1429, e-mail richard.long@ualberta.ca 


$\begin{array}{cl}\text { Chapter 5 } & \text { Nonrespiratory tuberculosis } \\ & \text { Victoria Cook, Richard Long } \\ \text { Chapter 6 } & \text { Treatment of tuberculosis disease and } \\ & \text { infection } \\ & \text { Vernon Hoeppner, Heather Ward, } \\ & \text { Kevin Elwood } \\ \text { Chapter 7 } & \text { Drug-resistant tuberculosis } \\ & \text { Richard Long, Monica Avendano, } \\ & \text { Lori Whitehead } \\ \text { Chapter 8 } & \text { Pediatric tuberculosis } \\ & \text { Ian Kitai, Patricia Malloy, Alice Kowalczyk, } \\ & \text { Richard Long } \\ \text { Chapter 9 } & \text { Tuberculosis and human immunodeficiency } \\ & \text { virus } \\ & \text { Stan Houston, Paul Brassard, } \\ & \text { Mark FitzGerald, Wendy Wobeser } \\ & \text { Nontuberculous mycobacterial disease } \\ & \text { Robert Cowie, Stephen Field, Anne Fanning }\end{array}$

Public health aspects of tuberculosis

Chapter 11 The role of public health in tuberculosis control

Robert Stirling, Donald Enarson

Chapter 12 Contact follow-up and outbreak management in tuberculosis control

Terry-Nan Tannebaum, Lillian Yuan,

Tamara Wallington

Chapter 13 Surveillance and screening in tuberculosis control

Wendy Wobeser, Lillian Yuan,

Brian Gushulak, Jerome Bickenback,

Elaine Randell

Chapter 14 Tuberculosis control in First Nations and

Inuit populations

Pamela Orr, Cheryl Case, Teresa Mersereau, Marcus Lem
Chapter 15 Immigration and tuberculosis control in Canada

Brian Gushulak, Sylvie Martin

Chapter 16 Tuberculosis control within institutions Dick Menzies, Michael Gardam

Chapter 17 Bacille Calmette-Guérin (BCG) vaccination in Canada Kevin Elwood, Mark FitzGerald

International aspects

Chapter 18

Canada and international tuberculosis control

Donald Enarson, Anne Fanning, Edward Ellis

Appendix A Contributors

Appendix B

Canadian Tuberculosis Surveillance System

Appendix C

Definition of terms

Appendix D Interferon-gamma release assays: Canadian

Tuberculosis Committtee advisory

committee statement

Appendix E Tuberculosis education and training resources

Appendix F BCG vaccine usage in Canada - current and historical

Appendix G Recommendations for the screening and prevention of tuberculosis in patients with human immunodeficiency virus (HIV) and the screening for HIV in tuberculosis patients and their contacts

Appendix $\mathrm{H}$ International standards for tuberculosis care

Appendix I Immigration and medical surveillance guidelines

Appendix J Ethical and legal considerations for tuberculosis surveillance and screening

Index 


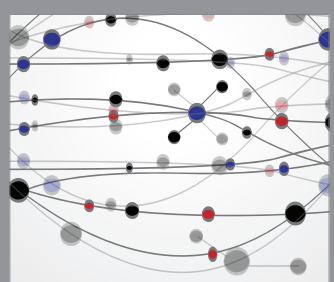

The Scientific World Journal
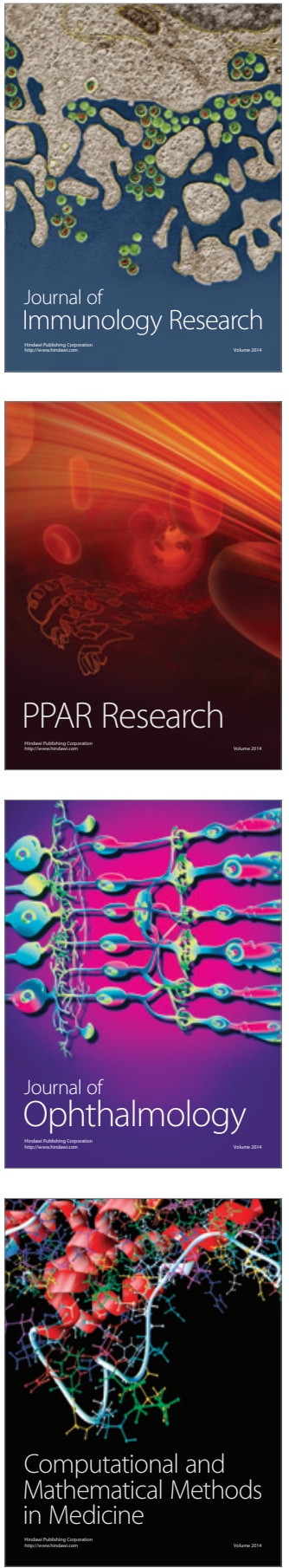

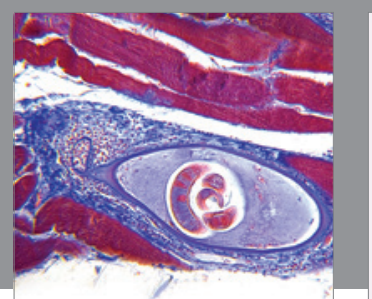

Gastroenterology Research and Practice

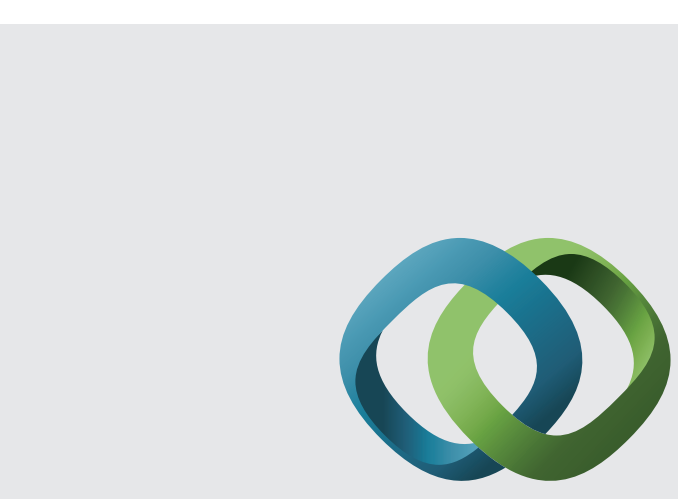

\section{Hindawi}

Submit your manuscripts at

http://www.hindawi.com
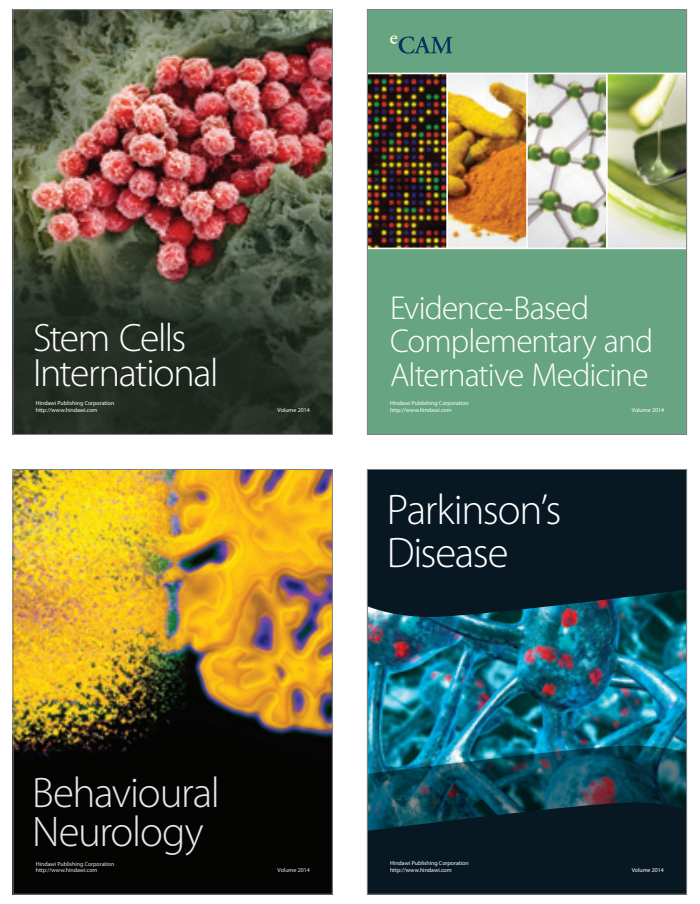
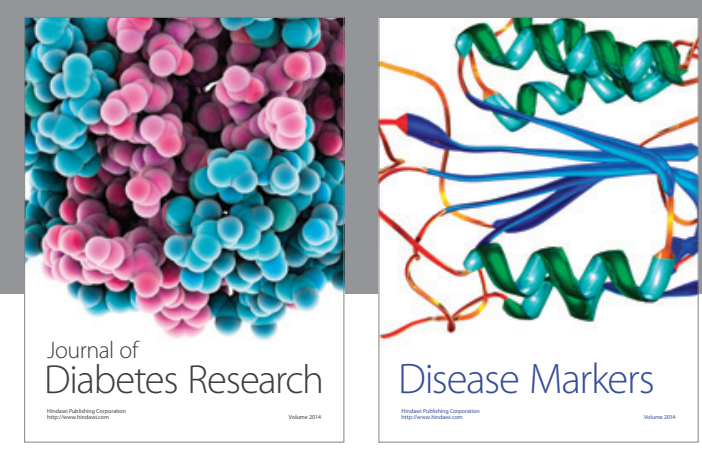

Disease Markers
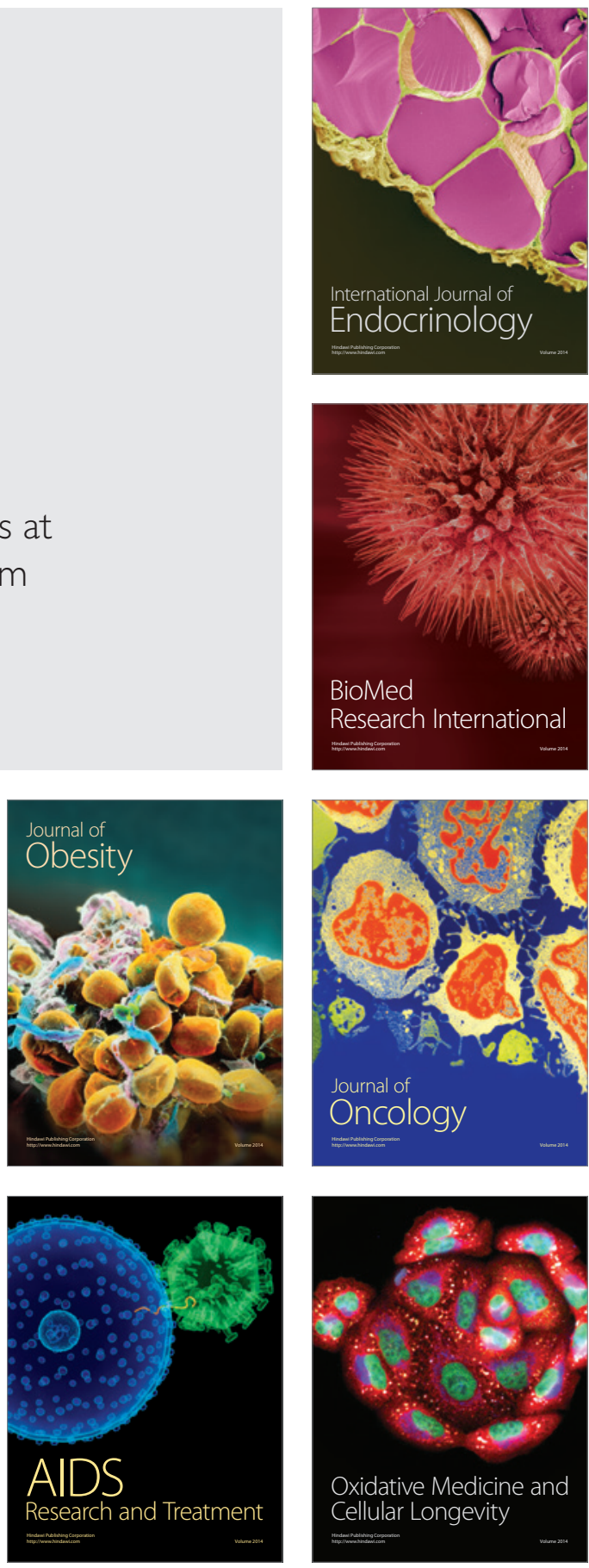